\title{
The Role of Water Resources Management in Reducing the Production Costs of Agricultural Products
}

\section{El papel de la gestión de los recursos hídricos en la reducción de los costos de producción de los productos agrícolas}

\author{
Ali Kariznovi \\ Ph.D. Student, Department of Geography and Urban Planning, Mashhad branch, Islamic Azad \\ University, Mashhad, Iran \\ ORCID: https://orcid.org/0000-0001-8418-3075

\section{Hamid Jafari} \\ Department of Geography, Mashhad Branch, Islamic Azad University, Mashhad, Iran \\ ORCID: https://orcid.org/0000-0002-2007-562X

\section{Katayoun Alizadeh} \\ Department of Geography, Mashhad Branch, Islamic Azad University, Mashhad, Iran \\ ORCID: https://orcid.org/0000-0001-7875-0977
}

Received 08-08-20 Revised 11-10-20

*Correspondence

Email: hamidjafari@yahoo.com
Accepted 01-11-21 On line 01-27-21

Cite as:
Kariznovi, A., Jafari, H., \& Alizadeh, K. (2021). The Role of Water Resources Management in Reducing the Production Costs of Agricultural Products. Propósitos y Representaciones, 9 (SPE2), e953. Doi: http://dx.doi.org/10.20511/pyr2021.v9nSPE1.953 


\section{Summary}

In order to achieve the goals of sustainable agricultural and rural development, agricultural education is an issue that should be in base considered and researched according to the importance of the issue and its related challenges must be realistically analyzed, Since water is one of the effective factors in the agricultural sector that plays a vital role in the production of agricultural products. There are several factors for low water productivity in the country, one of which can be considered non-optimal and unplanned use of water. It is clear that by increasing the level of awareness of farmers about the type of management of agricultural water resources it is possible to reduce current expenses and then to achieve high productivity and increasing income from crops and orchards. Therefore, in this study, the optimal management of water and reduction of production costs in the agricultural sector in Zabrkhan county of Neishabour city has been studied. The research method in this article was a descriptive- analytical method and the data was collected by two methods of library and field methods. The results show that the production cost per hectare of all crops in lands under water resources management is less than unmanaged lands. This rate varied between 3.4 to 16.8 percent. If we associate this reduction in production cost with product efficiency and use the cost per kilogram of production as a criterion, the reduction will be $165.2 \%$ for irrigated wheat, $150 \%$ for irrigated barley, $106.8 \%$ fodder corn and $54.4 \%$ for garden products. Therefore, according to the research results, the research hypothesis is confirmed.

Keywords: water resources management, production costs, area under cultivation, Zabrkhan county of Neishabour city

\section{Resumen}

Para lograr las metas de desarrollo agrícola y rural sostenible, la educación agrícola es un tema que debe ser en base considerado e investigado de acuerdo a la importancia del tema y sus desafíos relacionados deben ser analizados de manera realista, ya que el agua es uno de los factores efectivos. en el sector agrícola que juega un papel vital en la producción de productos agrícolas. Existen varios factores para la baja productividad del agua en el país, uno de los cuales puede considerarse un uso del agua no óptimo y no planificado. Está claro que al aumentar el nivel de conciencia de los agricultores sobre el tipo de manejo de los recursos hídricos agrícolas es posible reducir los gastos corrientes y luego lograr una alta productividad y aumentar los ingresos de los cultivos y huertos. Por tanto, en este estudio se ha estudiado la gestión óptima del agua y la reducción de los costes de producción en el sector agrícola del condado de Zabrkhan de la ciudad de Neishabour. El método de investigación en este artículo fue un método descriptivo-analítico y los datos fueron recolectados por dos métodos de biblioteca y métodos de campo. Los resultados muestran que el costo de producción por hectárea de todos los cultivos en tierras bajo manejo de recursos hídricos es menor que en tierras no administradas. Esta tasa varió entre el 3,4 y el 16,8 por ciento. Si asociamos esta reducción del costo de producción con la eficiencia del producto y tomamos como criterio el costo por kilogramo de producción, la reducción será del 165,2\% para el trigo de regadío, del 150\% para la cebada de regadío, del $106,8 \%$ de maíz forrajero y del 54,4\% para los productos de jardinería. Por tanto, según los resultados de la investigación, se confirma la hipótesis de investigación.

Palabras clave: gestión de recursos hídricos, costes de producción, superficie cultivada, condado de Zabrkhan de la ciudad de Neishabour 


\section{Introduction}

The agricultural sector has an important share in the country's GDP (Pishro and Azizi, 2009: 1). Because this sector has been able to gain a more favorable position than other economic sectors in terms of job creation, income generation and its share in GDP, population consumption needs and currency supply. On the other hand, by providing stability in food production, this sector can bring political stability (Ismaili Dastjerdipour et al., 2014: 132). According to most experts, the activities of the agricultural sector at different levels have important and fundamental roles. Among them, having a major role in achieving the development goals of the third millennium (sustainable development and poverty reduction) and so increasing in the income generation of rural poor in developing countries (Whelan, 2008: 7). In addition, moving towards sustainable development requires an appropriate education system and learning (Laurie et al., 2016: 226).

Water management in the agricultural sector is the most important strategy for sustainable development of the country and due to the development process of the country and the transformation of the national economy; the agricultural sector has become an important pillar of security and economic life of the country. On the other hand, for a country located in arid and semi-arid land and its average long-term annual rainfall, which is almost one third of the global average rainfall, reducing water consumption in the agricultural sector is one of the main goals. One of the solutions recommended to farmers to reduce water consumption and increase the efficiency of using irrigation water on the farm is to use modern irrigation systems and put aside the traditional irrigation systems (Jalili, 2017: 1).

Education is of great value and importance for any nation, both scientifically and socially. Considering that so far no study has been done on the effects of water resources management training on the agricultural development of Zabrkhan village in Neishabour city, therefore, this study seems necessary.

Zabrkhan County is one of the sections of Neishabour city, which is about $25 \mathrm{~km}$ away from the center of the city, which is almost rich in surface and groundwater resources due to its location in foothill area of Binalood. Some of must important rivers of this area are: Kharv river Dorood, Greeneh, Dizbad, and Kalshoor river. (Neishabour Governor's Portal, 2018). Due to the crisis of water resources in the under studied country, province, city and area, it seems that serious actions should be made for the water crisis in different dimensions and levels.

Considering the above, the main purpose of this study is to evaluate the impact of water resources management of villages on their agricultural development by a case study of villages of Zebarkhan county of Neishabour city of Iran as an arid and semi- arid located country in order to make a road map for water resources managers to manage this crisis. In this regard, the question is as follows:

What has been the impact of agricultural water resources management on reducing costs and so economic development of villages in Zabrkhan district of Neishabour city? According to the purposes of the research and also based on the question, the research hypothesis is as follows:

- There is a significant relationship between agricultural water resources management and reduction of production costs in the villages of Zabrkhan county of Neishabour city. 


\section{The Importance of the Subject}

Some of the general solutions to deal with the water crisis in the world can be preventing the development of irrigated agricultural lands, increasing water storage capacity (by dams and artificial feeding of aquifers), changing the management of water resources, increasing participation and cooperation in the basin International watersheds, the need to pay attention to the effects of climate change on water resources, valuing ecosystem and environmental factors and participation and exchange of views on the crisis caused by floods and droughts (Hosseinpour, 2006: 25). In Neishabour plain, the problem of water crisis has emerged as a result of disturbing the hydrological balance and increasing demand for water resources since the 1980s, and if the improper exploitation of water resources and a negative balance pattern of available resources is not stopped, gradually the volume of fresh and usable water will be reduced and the issue of water crisis will lead to the complete depletion of groundwater reservoirs in the plain and all investments will be lost. Neishabour plain is a part of Neishabour Kalshour watershed which is located in the northeast of the central desert of Iran. More than $70 \%$ of the crops in Neishabour region are irrigated, with the largest area under cultivation of grains and then industrial and horticultural products, which are high in terms of water requirements and are not compatible with the conditions of water shortage in the region.

Studies show that if the cultivation of aquatic plants (such as sugar beet, tomato, cotton, etc.) and water use methods continue in the traditional way and new technologies are not used in irrigation, in the not too distant future many villages in Zabrkhan district will be suffered from the acute problems caused by water shortage and dehydration, so that rural life will be seriously threatened, and villages that played an important role in the province's agricultural production will become food importers to meet their needs, and villagers will migrate to cities. It accelerates the migration of villagers to cities, especially develops suburbs, so it is necessary to carefully study the status of water resources and irrigation methods, and consider appropriate strategies for sustainable rural development with emphasis on optimal water management. Therefore, the present study is conducted accordingly.

\section{Theoretical Foundations}

Today, agriculture and agricultural development is playing the role of driving force of development in general and rural development in particular (Khalili, 2016: 30).

Agricultural development is discussed in the context of a country's national development and plays a vital role in national development as an important economic sector. The concept of agricultural development and its definition as a category of development in general has changed and evolved after the Second World War and various models of agricultural development have been designed and implemented by economists and experts (Hassani Nejad, 2010: 11) ).Attention to the agricultural sector is one of the main axes of development in most developing and developed countries. Because the agricultural sector is one of the main sources of employment and income in many countries, especially in developing countries and in this regard is responsible for ensuring food security and health as a national goal (Karimi et al., 2013: 78). Therefore, paying attention to improving productivity and the amount of return per unit area and finally, agricultural development is necessary in order to achieve economic development (Mohammadi Khayareh and Mazhari, 2017: 260). Historical evidence shows that man has long struggled with nature to supply water, especially in arid and semi-arid regions, so the water crisis has accompanied him throughout the history of human civilization. The water crisis in the 
present era from the dimension of water needs or demand for water and its scale from the local dimension in the past has become national, regional and global scales (Mozaffari, 2010: 3). Since the majority of the population of third World countries are rural, and their economies are also strongly dependent on agriculture, this can be achieved by improving the productivity and efficiency of agriculture and their dependent sectors. For the rural population, where agriculture is the main source of income, improving and increasing agricultural income is essential to improve welfare and overall economic development with a broad impact on the rural economy (Amini, 2008: 8).

Today, many researchers and scientists consider agricultural development as the main strategy for rural development and believe that agriculture as a major source of income and employment opportunities, plays a key role in rural development (Taghdisi and Bashaq, 2010: 137). To achieve this, there have always been several problems in the country's villages as a platform for agricultural activities, which have often had negative and detrimental effects on this sector. Among the characteristics of the current situation of rural agriculture, we can mention the small size of land plots and the separation of their agricultural land plots. Among the main challenges in agricultural development can be the lack of abilities and capabilities of agricultural development, high cost of agricultural technologies, lack of skilled manpower, poor access to the required software and hardware, limited supply of facilities and satellite equipment, the formal education which is not commensurate with the needs of the agricultural sector, and etc. (Bagheri and Bordbar, 2013: 100). Various policies are being implemented for the sustainable use of water, both by supply and demand. On the supply side, the use of effluents, desalination of seawater and the use of unconventional waters, and on the demand side, policies to reduce consumption and use solutions with high water efficiency (Lach \& et al, 2005: 83). The main problem of surface irrigation methods is low efficiency, which is due to poor irrigation management. By modifying surface irrigation systems in various ways such as land leveling, proper selection of irrigation methods, proper design and management of water in the field, it is possible to significantly increase irrigation efficiency (Absalan et al. 2007: 11- 25). Table (1) summarizes the literature related to the subject under study.

Table 1

\section{Research Background}

\begin{tabular}{|l|l|l|l|l|}
\hline Authors/ & & & Title & Result \\
& Writers & & & \\
\hline $\begin{array}{l}\text { Rasooli } \\
\text { Majd et al }\end{array}$ & & & $\begin{array}{l}\text { Optimizing the cultivation pattern } \\
\text { of Urmia plain using management } \\
\text { justification index based on water } \\
\text { footprint }\end{array}$ & $\begin{array}{l}\text { According to the results, the highest economic } \\
\text { justification among all selected crops in Urmia } \\
\text { plain is related to two walnut and almond crops } \\
\text { with advantage of 2 toward 3 compared other } \\
\text { horticultural and agricultural products. }\end{array}$ \\
\hline
\end{tabular}




\begin{tabular}{|c|c|c|c|c|}
\hline $\begin{array}{l}\text { Ebrahimi et } \\
\text { al }\end{array}$ & $\stackrel{\curvearrowright}{\stackrel{\imath}{~}}$ & $\stackrel{\frac{0}{0}}{\stackrel{2}{2}}$ & $\begin{array}{l}\text { Evaluating the Impact of Drip } \\
\text { Irrigation Systems on Energy } \\
\text { Consumption and Agricultural } \\
\text { Water Saving ) Case } \\
\text { Study : Kahriz Network, Urmia) }\end{array}$ & $\begin{array}{l}\text { The results of the control piezometer showed that } \\
\text { despite the continuing downward trend of } \\
\text { groundwater level changes in recent years, in the } \\
\text { year } 1971 \text { of the Kahriz drip irrigation system, the } \\
\text { minimum flow depth compared to the years } \\
\text { before the project has been relatively increased. }\end{array}$ \\
\hline $\begin{array}{l}\text { Dalir } \\
\text { Esfiokhi }\end{array}$ & $\stackrel{े}{\vec{\partial}}$ & 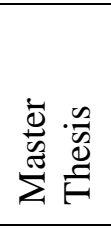 & $\begin{array}{l}\text { Investigating the effect } \\
\text { of climate change on water resour } \\
\text { ces management and cultivation } \\
\text { pattern } \\
\text { The basin watershed Gharehghom }\end{array}$ & $\begin{array}{l}\text { High-yield crops with high water consumption } \\
\text { reduced and the areas for the crops with lower } \\
\text { consumption was increased. Generally the level of } \\
\text { water consumption was decreased and also the } \\
\text { farming income was decreased. }\end{array}$ \\
\hline $\begin{array}{l}\text { Ahmad Ali } \\
\text { et al }\end{array}$ & $\stackrel{\infty}{\stackrel{\sim}{i}}$ & $\stackrel{\frac{0}{0}}{\stackrel{2}{2}}$ & $\begin{array}{l}\text { Assess the impact of water } \\
\text { management scenarios, climate } \\
\text { change effects on the environment } \\
\text { and } \\
\text { sustainability. CASE agriculture } \\
\text { STUDY : basin watershed } \\
\text { of Zarina rood, and Simineh } \\
\text { rood River }\end{array}$ & $\begin{array}{l}\text { The results showed that the highest values of } \\
\text { environmental and agricultural sustainability } \\
\text { indices is for the scenario of combination of } \\
\text { cultivation pattern change with irrigation total } \\
\text { efficiency improvement publication } 1(4 \mathrm{~S} 1 \mathrm{~B}) \mathrm{B} \text {. } \\
\text { By this scenario, the amount of the input annual } \\
\text { average flow to Urmia lake from the Zarinneh } \\
\text { rood and Siminieh rood rivers was equal } 1292 \text { and } \\
351 \text { million cubic meter and so the environmental } \\
\text { needs of the lake will be supplied by these two } \\
\text { basins. }\end{array}$ \\
\hline $\begin{array}{l}\text { Saed and } \\
\text { Amini }\end{array}$ & 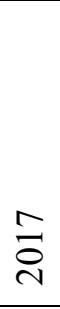 & 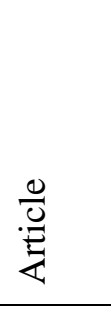 & $\begin{array}{l}\text { Comprehensive management of } \\
\text { water resources in agriculture and } \\
\text { modification of cultivation pattern } \\
\text { using the concept of water } \\
\text { footprint and its relationship with } \\
\text { drought, economy and water trade }\end{array}$ & $\begin{array}{l}\text { The results show that achieving equilibrium in } \\
\text { order to improve the cultivation pattern to better } \\
\text { manage water resources at the sub-basin, basin, } \\
\text { provincial and even national scales is possible.. }\end{array}$ \\
\hline $\begin{array}{l}\text { Ismaili } \\
\text { Khoshmora } \\
\text { dan }\end{array}$ & $\stackrel{\curvearrowright}{\grave{\lambda}}$ & 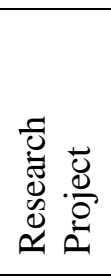 & $\begin{array}{l}\text { Investigation of water efficiency } \\
\text { and its management pathology in } \\
\text { the agricultural sector of the } \\
\text { country Iran }\end{array}$ & $\begin{array}{l}\text { Since water is one of the factors in the agricultural } \\
\text { sector that plays a critical role in the production of } \\
\text { agricultural products. Therefore, in this study, the } \\
\text { optimal management of water and increasing the } \\
\text { productivity of this production factor in the } \\
\text { agricultural sector has been investigated. }\end{array}$ \\
\hline $\begin{array}{l}\text { Jangchi } \\
\text { Kashani et } \\
\text { al }\end{array}$ & $\stackrel{\overbrace{}}{\check{c}}$ & $\begin{array}{l}\frac{1}{8} \\
\dot{0} \\
\infty\end{array}$ & $\begin{array}{l}\text { Water resources } \\
\text { sustainable } \\
\text { development }\end{array}$ & $\begin{array}{l}\text { Investigation of resource management and water } \\
\text { productivity indicators in agriculture }\end{array}$ \\
\hline Waziri et al & $\stackrel{0}{\stackrel{0}{\circ}}$ & $\stackrel{\frac{0}{0}}{\stackrel{2}{2}}$ & $\begin{array}{l}\text { The effect of economic pricing of } \\
\text { irrigation water on the cultivation } \\
\text { patterns in plain Dehgolan }\end{array}$ & $\begin{array}{l}\text { The cost of water extraction is } 634.3 \text { Rials per } \\
\text { cubic meter. So the difference between extraction } \\
\text { cost with its economic value in this plain is } 1878.3 \\
\text { Rials, and with consideration of a water pricing } \\
\text { policy toward its economic value, it will be } \\
\text { resulted in decrease in water consumption and the } \\
\text { cultivation area for low efficiency crops. }\end{array}$ \\
\hline
\end{tabular}

\section{Methodology}

The method of the present research is applied in terms of purpose and descriptive and analytical in terms of nature. In this research, in order to collect information, two methods of documentation and library (non-field) and referring to the region and conducting interviews 
with experts of agricultural jahad office, villagers of the studied villages and exploiters (field) have been used.

The dependent variable of the present study is "agricultural development" and the independent variable is "reduction of production costs".

Then, after collecting information, basic information tables related to the hypothesis were prepared. Finally, by performing the necessary calculations and extracting the performance differences in each field, the data were analyzed and the results were extracted, then the hypothesis was tested by adapting the obtained results.

\section{Introducing the Study Area}

Zabrkhan County is one of the six sections of Neishabour city. This county is limited to the Torqabeh county of Mashhad from the north, to the Ahmadabad county of Mashhad from the east, to the Kadkan county of Torbat Heydariyeh from the south, to the central area and the middle of the Neishabour plain from the west. The number and distribution of the rural population of Zabrkhan by village is shown in Table 2.

Table 2

Number of population and household $\operatorname{size}^{1}$ in Zabarkhan county of Neishabour by village in 2016

\begin{tabular}{|l|l|l|l|}
\hline County & $\begin{array}{l}\text { Number of } \\
\text { Population }\end{array}$ & Number of Families & $\begin{array}{l}\text { Household } \\
\text { Dimension }\end{array}$ \\
\hline Eshagh Abad & 11260 & 3445 & 3.26 \\
\hline Ordoo Ghash & 21693 & & 7153 \\
\hline Zebarkhan & 23682 & 7714 & 3.03 \\
\hline Zebarkhan County & 56635 & 18312 & 3.07 \\
\hline
\end{tabular}

Source: Zabrkhan county office and author's calculation

According to Table 2 in 2016, the most population was living to Zabarkhan rural district and the least population was living to Eshaqabad rural district. In addition, the household size of Zabarkhan district was 3.09.

\section{Results}

Zabrkhan county, due to its location in the mountain foothill region of Binalood mountain range and having a mild mountainous climate, has suitable conditions for agricultural activities and the basis of livelihood and production system in this county is based more on agricultural activities. Agriculture in Zabrkhan county in both traditional and industrial forms is common, and the activities of farmers mostly include agriculture and horticulture. Major crops such as wheat, barley, fodder corn, tomatoes and canola and horticultural products also include: plums, apricots, peaches, apples, cherries, pistachios and saffron, which saffron as the most expensive agricultural and spice products in the world has a special place among the products.

\footnotetext{
1 - The meaning of Family Size and Family Dimension is the number of family members.
} 
Table 3

Area under cultivation of agricultural lands in Zabrkhan county during the crop year 2017-2018(hectares)

\begin{tabular}{|l|l|l|l|l|l|}
\hline \multicolumn{2}{|l|}{ Crop Lands } & Garden Lands & \multicolumn{3}{l|}{ Total } \\
\hline Irrigated & Dry & 7104 & Irrigated & Dry & Total \\
\hline 7600 & 300 & & 14704 & 300 & 15004 \\
\hline
\end{tabular}

Source: Yearbook of Agricultural Jahad office of Khorasan Razavi Province, 2019

\section{Farming}

The people of the village seek their livelihood in various ways and use various sources as their means of income that usually agricultural activities are more important to the villagers than other occupations (Bazobandi, Arfai, 2006: 183). Farming is one of the basic pillars of human life on the planet. By cultivating crops, human beings are able to prepare the types of food they need (Rastegar, 2014: 2). In the study area, farming has an effective role in rural economy.

\section{Income and Employment of Major Agricultural Products}

Information on income and employment of major crops is given in Table 4.

\section{Table 4}

Income and employment created from major agricultural products in the villages of Zabrkhan district during the crop year 2017-2018

\begin{tabular}{|l|l|l|l|l|l|l|l|}
\hline Crop & $\begin{array}{l}\text { Cultiva } \\
\text { ted } \\
\text { Area }\end{array}$ & $\begin{array}{l}\text { Perfor } \\
\text { mance } \\
\text { Kilogr } \\
\text { am/ } \\
\text { Hectar } \\
\text { e }\end{array}$ & $\begin{array}{l}\text { Gross } \\
\text { Revenue } \\
\left(\text { Toman }^{2}\right) .\end{array}$ & $\begin{array}{l}\text { Productio } \\
\text { n Cost in } \\
\text { each } \\
\text { Hectare } \\
\text { (Toman) }\end{array}$ & $\begin{array}{l}\text { Total Net } \\
\text { Income( } \\
\text { Toman) }\end{array}$ & $\begin{array}{l}\text { Household } \\
\text { Income(To } \\
\text { man) }\end{array}$ & Employment(Person) \\
\hline $\begin{array}{l}\text { Irrigated } \\
\text { Wheat }\end{array}$ & 1650 & 5500 & 7425000 & 3200000 & $\begin{array}{l}697125000 \\
0\end{array}$ & 380693 & 183 \\
\hline $\begin{array}{l}\text { Irrigated } \\
\text { Barley }\end{array}$ & 2250 & 5000 & 5950000 & 2900000 & $\begin{array}{l}686250000 \\
0\end{array}$ & 374754 & 250 \\
\hline Corn & 600 & 50000 & 20000000 & 2700000 & $\begin{array}{l}103800000 \\
00\end{array}$ & 566841 & 133 \\
\hline Tomato & 300 & 40000 & 48000000 & 7000000 & 123000000 & 671691 & 67 \\
\hline
\end{tabular}

2 - The exchange rate for Iranian currency at the research time had been 42460 Rial per Dollar or 4246 Toman per Dollar. 


\begin{tabular}{|l|l|l|l|l|l|l|l|}
\hline & & & & & 00 & & \\
\hline Canola & 50 & 2000 & 5720000 & 3200000 & 126000000 & 6881 & 6 \\
\hline Total & 4850 & - & 87095000 & 19000000 & $\begin{array}{l}366397500 \\
00\end{array}$ & 2000860 & 639 \\
\hline
\end{tabular}

Source: Jahad Keshavarzi agriculture office of Zabrkhan district, Statistical yearbook of Jahad Keshavarzi, Khorasan Razavi, 2019 and author calculations.

Based on the results obtained from Table 4, the total net income from crops is estimated equal to 36639750000 tomans. 18312 households lived in rural areas of Zabrkhan district in 2016. Based on this, the share of each rural household in the net income of major agricultural products of Zabrkhan district was 2000860 Tomans, which was the highest share of rural household income from tomatoes. The total employment created through agriculture in the region was 639 jobs that the most share was for irrigated barley.

\section{Gardening}

Among the most important factors in the production of horticultural products, geographical conditions, especially climate, minimum winter and maximum summer temperatures, growing season length, temperature during the growing season, light intensity, rainfall and precipitation regime, are the factors that are playing a great role in prodction of these products and their variety. (Motiei Langroudi, 2003: 159). Planning for gardens is very different from cultivating agricultural crops. Planning for farming is short-term and usually one year, but planning for horticulture is long-term and usually 30 to 50 years old, so if planning for a crop go in a wrong way the lose will be for just one year, but if we make a mistake in planning to build an fruit garden, we will have a problem for 30 to 50 years.

\section{Income and Employment of Major Garden Products}

The study area is one of the important areas for fruit production, especially plum production and its export to Germany, Italy and the Persian Gulf countries, due to the favorable climatic conditions and fertile land and abundant water, which generates a lot of income and employment for the youth of the region and has caused a lot of currency for the country. Plum is a fruit that is consumed as a dried fruit, medicinal and food, rather than freshly eaten. 
Table 5

Income and employment generated from major horticultural products in the villages of

\begin{tabular}{|c|c|c|c|c|c|c|c|c|}
\hline $\begin{array}{l}\text { Employ } \\
\text { ment }\end{array}$ & $\begin{array}{l}\text { Employ } \\
\text { ment } \\
\text { Days }\end{array}$ & $\begin{array}{l}\text { Per } \\
\text { Household } \\
\text { Income } \\
\text { (Toman) }\end{array}$ & $\begin{array}{ll}\text { Total Net } \\
\text { Income } \\
\text { (Toman) }\end{array}$ & $\begin{array}{l}\text { Per } \\
\text { Hectare } \\
\text { Income } \\
\text { (Toman) }\end{array}$ & $\begin{array}{l}\text { Per } \\
\text { Hectare } \\
\text { Producti } \\
\text { on Cost } \\
\text { (Toman) }\end{array}$ & $\begin{array}{l}\text { Perfor } \\
\text { manc } \\
\text { e } \\
\text { Kgm/ } \\
\text { Hecta } \\
\text { re }\end{array}$ & $\begin{array}{l}\text { Cultiv } \\
\text { ation } \\
\text { Area } \\
\text { (Hecta } \\
\text { re). }\end{array}$ & Crop \\
\hline 661 & 178380 & 7387041 & $\begin{array}{l}1352715000 \\
00\end{array}$ & 55000000 & 9500000 & 11000 & 2973 & Plum \\
\hline 48 & 12840 & 590159 & $\begin{array}{l}1080700000 \\
0\end{array}$ & 60000000 & 9500000 & 12000 & 214 & Apple \\
\hline 6 & 1500 & 45735 & 837500000 & 40000000 & 6500000 & 10000 & 25 & Peach \\
\hline 7 & 1800 & 135157 & 2475000000 & 90000000 & 7500000 & 9000 & 30 & $\begin{array}{l}\text { Aprico } \\
\mathrm{t}\end{array}$ \\
\hline 96 & 25800 & 1937254 & $\begin{array}{l}3547500000 \\
0\end{array}$ & 90000000 & 7500000 & 9000 & 430 & Cherry \\
\hline 270 & 72960 & 1195282 & $\begin{array}{l}2188800000 \\
0\end{array}$ & 28000000 & $\begin{array}{l}1000000 \\
0\end{array}$ & 700 & 1216 & $\begin{array}{l}\text { Pistac } \\
\text { hio }\end{array}$ \\
\hline 1580 & 426600 & 1941350 & $\begin{array}{l}3555000000 \\
0\end{array}$ & 30000000 & 7500000 & 5 & 1580 & $\begin{array}{l}\text { Saffro } \\
n\end{array}$ \\
\hline 2668 & 719880 & 13231978 & $\begin{array}{l}2423040000 \\
00\end{array}$ & - & - & - & 6468 & Total \\
\hline
\end{tabular}

Zabrkhan district during the 2017-18 crop year.

Source: Jahad Keshavarzi Agriculture Office of Zabrkhan district, statistical yearbook of Jahad Keshavarzi of Khorasan Razavi and author's calculations

Based on the results obtained from Table 5, the total net income from horticultural products is estimated at 24,230,400,000 Tomans. The share of each rural household was 13231978 Tomans. Plums takes the most share of household income. In total, horticultural products have created 2668 jobs in the 2017-18 crop year. By this number, saffron with 1580 jobs has the highest number of employees

\section{Conclusion}

The results of studies conducted about the reduction of production costs in the study area show that the cost of production per hectare of all crops in lands under water resources management is less than unmanaged lands. This rate varied between 3.4 to 16.8 percent. If we relate this 
reduction in production cost to product efficiency and then consider the cost per kilogram of production as a criterion, the reduction will be: $165.2 \%$ irrigated wheat, $150 \%$ Irrigated barley, $106.8 \%$ Fodder corn and finally for Gardens $54.4 \%$.

Therefore, according to the research results, the research hypothesis is confirmed.

Table 6

Reduction of production costs in managed and unmanaged lands in (hectares) of Zebarkhan county in $2018^{3}$

\begin{tabular}{|c|c|c|c|c|c|c|c|}
\hline \multirow[b]{2}{*}{ Row } & \multirow[b]{2}{*}{ Crop } & \multicolumn{2}{|c|}{$\begin{array}{l}\text { Production Cost Per } \\
\text { Hectare( Rial) }\end{array}$} & \multirow{2}{*}{$\begin{array}{l}\text { Differen } \\
\text { ce } \\
\text { Percent }\end{array}$} & \multicolumn{2}{|c|}{$\begin{array}{l}\text { Production Cost } \text { Per } \\
\text { Kilogram( Rial) }\end{array}$} & \multirow{2}{*}{$\begin{array}{l}\text { Difference } \\
\text { Percent }\end{array}$} \\
\hline & & $\begin{array}{l}\text { For } \\
\text { Managed } \\
\text { Lands }\end{array}$ & $\begin{array}{l}\text { For } \\
\text { Unmanag } \\
\text { ed Lands }\end{array}$ & & Managed & $\begin{array}{l}\text { Unmanage } \\
\text { d }\end{array}$ & \\
\hline 1 & Wheat & 30000000 & 35000000 & -16.7 & 6000 & 15909 & 165.2 \\
\hline 2 & Barley & 28000000 & 30000000 & -7.1 & 6667 & 16667 & 150 \\
\hline 3 & Corn & 58000000 & 60000000 & -3.4 & 829 & 1714 & 106.8 \\
\hline 4 & $\begin{array}{l}\text { Garde } \\
\mathrm{ns}\end{array}$ & 95000000 & $\begin{array}{l}11000000 \\
0\end{array}$ & -15.8 & 5938 & 9167 & 54.4 \\
\hline
\end{tabular}

Source: Agricultural Jahad Office of Zabrkhan county, exploiters, villagers and the author's calculations

The results also show that the production cost per hectare for all crops in knowledge-based management lands was lower than in traditional management lands. This rate varied between 54.4 and 165.2 percent. Traditional agriculture in the scope of this study, although for sub-areas may currently have advantages in terms of employing more labor, especially family members and dense farming, but in an overview of the current cultivation pattern, as well as the high wages versus semi-industrial agriculture, is not cost-effective and costs will increase more during the planting process.

\section{Suggestions}

- Use of new technologies in irrigation of fields such as; Low irrigation methods, drip irrigation and development of field irrigation systems along with training farmers and farmers in how to properly use and protect irrigation networks

- Provide financial support through banks to set up a pressurized irrigation system on farms.

- Agricultural Office must consider the priority of allocation the products insurance subsidies for the farmers who consider the regional- national cultivation pattern.

3- The Difference Percentage is extracted from the formula below:

$D P=\frac{\text { The Unmanaged Farms Costs }}{\text { The Managed Farms Costs }} \times 100$ 
- The use of traditional methods in irrigation causes water wastage, plant nutrients to be taken below the roots, less cultivated area, more cost and weeds increase.

- Supporting the development of greenhouses and the transfer of cultivation from open space to controlled space and recycling of wastewater, unconventional water management and virtual water management.

- Implementation of land use change policy in cultivation pattern based on comparative advantage.

- Implementation, monitoring and proper operation of modern irrigation methods.

- Covering streams and irrigation networks of the country, land leveling and integration of agricultural lands.

- Proper pricing of water and agricultural products and the study of the impact of these prices on production and land cultivation.

\section{References}

Absalan, S, E. Dehghan, F. Abbasi, N. Heydari, H. Farahani, A. Javadi, H. Siadat, \& T. Oweis. (2017). Evaluation of the best management practices for improving water productivity in the saline areas of lower Karkheh River Basin (KRB). Proceedings of the International Workshop on Improving Water Productivity and Livelihood Resilience in Karkheh River Basin, 11- 25.

Ahmad Ali, J., Barani, Gh., Ghaderi, K., \& Hesari, B. (2018). Evaluation of water management scenarios and the impact of climate change on environmental and agricultural sustainability (Case study: Zarrinehrood and Siminehrood Watershed basins). Scientific Journal- Alco Hydrology Research, 5(4), 89-102 (In Persian).

Amini, G. (2008). Causes of rural migration in planning for population balance between urban and rural areas of Dashti city, M.Sc. Thesis, Department of Geography, University of Isfahan. (In Persian).

Bagheri, N., \& Bordbar, M. (2013). Identifying the challenges facing the development of precision agriculture in Iran. Journal of Agricultural Extension and Education Research, 2(6), 97-107. (In Persian).

Bazobandi, H., \& Arfai, T. (2006). Geography of Torqabeh and Mashhad, Sonboleh Publications (In Persian).

Dalir Esfiyokhi, M. (2019). Investigating the effect of climate change on water resources management and cultivation pattern in Qaraqoom watershed, Master Thesis, Faculty of Agriculture and Natural Resources, Torbat Heydariyeh. (In Persian).

Ebrahimi, M., Zeinalzadeh, K., Besharat, S., \& Alizadeh Berdouki, A. (2019). Evaluation of the effect of drip irrigation systems on energy consumption and agricultural water saving (Case study: Kahriz network of Urmia), the first international congress and Fourth National Congress of Irrigation and Drainage of Iran, Urmia (In Persian).

Hassani Nejad, A. (2010). Agricultural Development with Emphasis on the Transition from 
Traditional Agriculture to Sustainable Agriculture in Zarrin Dasht, Master Thesis in Geography and Rural Planning, University of Isfahan, Supervisor, Allah Nouri, Hedayat. (In Persian).

Ismaili Dastjerdipour, A., Chizari, M., \& Sedighi, H. (2014). An Institutional Approach to Development in the Agricultural Sector. Journal of Planning and Budget, 3(19), 131149. (In Persian).

Ismaili Khoshmoradan, A. (2017). study of water efficiency and its management pathology in the agricultural sector, research project, Office of Research and Policies of Production Sectors, Ministry of Economic Affairs and Finance (In Persian).

Jalili, M. (2017). Irrigation efficiency (do's and don'ts). Journal of Water and Sustainable Development, 4(1), 76-88. (In Persian).

Jangchi Kashani, S. (2017). Water Resources Management in Sustainable Agricultural Development, Academic Publications. (In Persian).

Karimi, Asef. (2013). Designing an Organizational Entrepreneurship Model for Agricultural Extension in the Field of Sustainable Agricultural Development. Iranian Journal of Agricultural Research and Development, 1(44), 77-93. (In Persian).

Lach, D., Rayner, S. \& H. Ingram. (2005). Maintaining the Status Quo: How Institutional Norms and Practices Create Conservative Water Organizations. Texas Law Rev, 83(7), 2027-2053.

Laurie, R., Monoyama-Tarumi, Y., Mceown, R., \& Hopkins, C. (2016). Contributions of education for sustainable development (ESD) to quality education: A synthesis of research. Journal of Education for Sustainable Development, 10, 2, 226-242.

Mohammadi Khayareh, M., \& Mazhari, R. (2017). A Study of the Interaction of Economic Growth and Development of the Agricultural Sector in Iran. Journal of Agricultural Economics Research, 4(4), 259-282. (In Persian).

Motiei Langroudi, H. (2003). Economic Geography of Iran, Mashhad University Jahad Publications. (In Persian).

Mozaffari, G. A. (2010). The Global Water Crisis, Challenges and Solutions with Emphasis on Israel, Fourth International Congress of Geographers of the Islamic World. (In Persian).

Pishro, H., \& Azizi, P. (2009). Development of sustainable agriculture through stabilization of agricultural incomes. Journal of Human Geography, 4(1), 1-19. (In Persian).

Rasouli Majd, N., Montaseri, M., \& Amir Ataei, B. (2019). Optimizing the cultivation pattern of Urmia plain using water justification management index based on water footprint, the first international congress and the fourth national congress of irrigation and drainage of Iran, Urmia (In Persian).

Saed, B., \& Amini, D. (2017). Comprehensive management of water resources in agriculture and cultivation pattern modification using the concept of water footprint and its relationship with drought, economics and water trade, 14th National Conference on Irrigation and Evaporation Reduction, Kerman (In Persian). 
Taghdisi, A., \& Bashaq, M. R. (2010). Agricultural challenges and their impact on rural population with emphasis on changes in cultivated area. Quarterly Journal of Rural Research, 2(1), 137-161. (In Persian).

Vaziri, A., Vakilpour, M. H., \& Mortazavi, A. (2016). The effect of economic pricing of irrigation water on the pattern of cultivation in Dehgolan plain. Agricultural Economics Research, 8(3), 34-50. (In Persian). 